\title{
Cadastral Identification of Real Estate Property
}

\section{Cristina Mihaela ONICA ${ }^{\star}$}

\begin{tabular}{l}
\multicolumn{1}{c}{ A R T I C L E I N F O } \\
\hline Article history: \\
Accepted December 2019 \\
Available online December 2019 \\
\hline JEL Classification \\
R30, R33 \\
Keywords: \\
Cadastral, Real estate properrty \\
\hline
\end{tabular}

\author{
A B S T R A C T \\ The approached field presents a display of the role of real estate knowledge, the cadastral \\ surface, for a correct evaluation process of real estate properties, three sides of cadastral \\ survey, and namely, the technical, the economic and the judicial side, in order to accurately \\ reflect the information needed for the evaluation process.
}

(C) 2019 EAI. All rights reserved.

\section{Introduction}

Real estate markets can be studied from more perspectives - geographic, competitive, and from the features of demand and offer. The evaluator considers the value of the real estate property in the context of real estate markets, the delimitation of real estate markets being a basic aspect of evaluation. Real estate evaluation firstly considers assessing the market value, as well as the profitableness of a fixed good as investment value. Consultancy studies in evaluation are carried out in order to determine and explain the markets' features to the clients. An evaluator understands the market of a real estate property as being reflected by the criteria used to analyze, select and explain the comparisons to other real estate properties.

\section{Cadaster - data sources in the evaluation activity}

The cadastral documentation provides information regarding the surface of the field/area, the built, usable or habitable surface of a building, the coordinates and the shares of the points that define the limits of the properties, the orientation of the field surface or of a building reported to the cardinals, the opening of a field, the wearing degree of a building, the condition of the building, the structure type of the building and many other pieces of information. These ones are found in the cadastral files and in the real estate register, documents which first come in hand to the evaluator.

The objective of the cadaster is to determine technical, economic and judicial information regarding the real estate properties, to ensure the publicity of the real estate rights, based on which these rights were founded, transferred, modified or ended, to support the taxation system and to contribute to the security of real estate transactions and the easing of real estate mortgage.

A particular problem that has called into question since there was still in force Law No 32/1968 (the former law concerning the legal regime of offenses) and that is still arousing interest for the specialists and practitioners practice is the issue of limitation in for lifting of unauthorized construction. The thorniest part of the problem relates to the time when this term flows, if it could be invoked by the authorities or by the offender in case of subsequent obtaining of authorisation after the discovery of a contraventional act.

The cadastral identification of the real estate property is the first stage of the evaluation process, according to the figure below:

\begin{tabular}{ll|}
\hline I. PROBLEMIDENTIFICATION \\
- Property identification; \\
- & The use of evaluation; \\
- & The definition of value; \\
- & The date of evaluation;
\end{tabular}

- The scope of evaluation;

- Other limiting conditions;

Figure 1. Cadastral identification within the real estate property 


\section{Conceptual delimitations regarding the cadastral survey}

The real estate register displays the buildings' descriptions and information regarding the real estate rights, individual rights, the judicial acts, facts or reports that regard the real estate goods. According to law 18/1991, the agricultural real estate includes any type of fields, irrespective of use, the title based on which they are owned and the public or private field they belong to.

Immovable - represents the field, with or without buildings, on the surface of an administrativeterritorial unit, belonging to one or more owners, identified through a unique cadastral number.

Allotment - is the surface with a single use.

The usage category of the field is emphasized by a code which represents the features of the field allotment and is established depending on the natural conditions - relief, altitude, soil type.

Cadastral plans are displayed by different scale plans, namely the graphic representation of the immovable in an administrative-territorial unit, which are registered in the real estate register, classified in a cadastral manner.

The sheet plan extract -represents a part of the cadastral plan which includes the representation of the immovable, as well as the neighboring immovable, the dimensions of their sides.

The cadastral sector is represented by a part of an administrative-territorial unit, limited by linear, time stable elements, such as roads, waters, dams, railroads and others.

Through the technical function of cadaster, we determine the position of the limits between the neighboring immovable, the surface of the fields and constructions resulted from the measurements.

The economic function of cadaster emphasizes the elements that are needed to assess the taxable value of the immovable good.

The judicial function of cadaster is given by the identification of the real estate goods' owners and their recording in the land register. destination:

Usage groups of the fields, according to art. 2 Law 18/1991, are classified depending on their usage

1. The group of agricultural fields - TDA

2. The group of forest fields - TDF

3. The urban area fields - TDI

4. The permanent under water fields $-\mathrm{TDH}$

5. The special usage fields - TDS

\section{Useful information for the evaluation activity included in the specialty cadaster}

The specialty cadaster provides information for the evaluation of fields, which is needed for the assessment of the market value or for their taxation value.

\subsection{The cadaster of the agricultural land register is represented by the agricultural fields outside the} urban area, symbolized by the TDA code.

The regulatory frame work is provided by:

- The Law of the Agricultural real estate 18/1991 reissued in the "Monitorul Oficial" no.1/01.05.1998, with subsequent changes and completes.

- Law of vinery and wine no 67/1997 repealed and replaced by Law $244 / 2002$

- GO 34/2000 regarding the ecologic agri-food products

- Law of fruit growing 348/2003, reissued at $14^{\text {th }}$ of November 2012

- GO 34/2013 regarding the organization, management and the exploitation of permanent meadows and for the modification and completion of the agricultural real estate law.

Agricultural fields are ranked depending on the quality in five classes from I to $\mathrm{V}$ and on their production capacity in 3 classes from A to C. The cadaster of the vinery real estate is a subsystem of the agricultural real estate and in classified in six classes, as follows:

Class 1 - fields with no limitations or restrictions

Class 2 - fields with low limitations or restrictions

Class 3 - fields with medium limitations or restrictions

Class 4 - fields with severe limitations or restrictions

Class 5 - fields with severe limitations or restrictions that can be adjusted

lass 6 - fields with severe limitations or restrictions that cannot be adjusted

\subsection{The cadaster of real estate fund is a subsystem of the general cadaster symbolized through the TDI code.}

The regulatory framework is provided by the MLPAT order and the president's ONCGC no 90/N/911 and 912-CP/2 from 1997, by law 50/1991 updated in 2014, regarding the authorization of construction 
activities and by the HG 525/1996 reissued in Nov. 2002 and updated in June 2011 for the approval of the general urbanism regulation.

\subsubsection{The classification of constructions and their cadaster indexes}

Buildings and constructions are classified after their purpose of use as such:

- $\quad \mathrm{CL}$ - constructions designed for living

- CAS - administrative and socio-cultural constructions

- $\quad$ CIE - industrial and municipal constructions

- $\quad$ CA - annex constructions

\subsubsection{Information needed for the general real estate cadaster}

According to ONGC no. 90/N/911-CP/2 in 1997, the following data is being registered in the general real estate cadaster: the purpose of use, use, number of floors, number of basements, structure, foundation, walls, roof, heating, municipal equipment, condition of the construction, year of construction, propriety type, management method, capacity type, number of families, and number of individuals.

4.3. The cadaster of the municipal estate register represents the inventory of the underground, surface and over ground municipal equipmentfrom the interior of urban area buildings, such as the water supply network, the heating network, the electricity supply network, the communication network and others.

\section{Real estate publicity and the real estate register}

Real estate goods and rights of owners are registered in the public documentation through the real estate register. The real estate publicity system comes to judicially protect the ownership right. The mean through which real estate register is made is the real estate publicity cadaster registry, where all the cadastral activities and judicial documents regarding propriety are registered. According to art. 23 from Law 7/1996 reissued, the real estate register consists of the title, displaying the number and the name of the location where the real estate is located, continuing with:

- Part I which consists of a description of the real estate good which includes the order number and the cadaster number, purpose and category use and the plan of the real estate good and its description.

- Part II includes data regarding the ownership right and other real rights: name of the owner, propriety title, propriety transfers, management rights, community servitudes, judicial facts regarding propriety, reception and rejection of the dismemberment/merging proposal, alienation interdictions, inalienability clauses of the building (see art 628 of the Civil Code) and any other modifications, adjustments or notes that would be made in the title in part I and II.

- Part III - information regardingthe registrations about the property right dismemberments, the real warranty rights and duties, namely: the surface, use, habitation rights, servitudes regarding the purpose of use, the mortgage and real estate benefits, judicial facts, sequester, construction surveillance or its revenues and any other changes, adjustments or other notes that would be made regarding the information in this category.

Notes in the land register are classified in three categories, as follows: - permanent entry - real estate registration, temporary - undefined and actuaries' entries.

\section{Scales of conventional plans. Conventional signs}

In the case of a cadaster plan, it is important for the conventional signs used for the representation on field elements on plans to be known; thus, information will be understood and easily used when evaluating the building/property.

The cadaster plan provides information on the position of an element/field point, the real size such as length, distances or surface area, by applying different graphic or analytic methods, using the formula of numeric scale.

A cadaster plan is made using a numerical scale expressed by the 1:n ration and allows the passing from the distance between two points of the cadaster plan, its D correspondence in the field, the value of $n$ in the field is $1 \mathrm{~mm}$.

The field is displayed with higher details when the representation scale is higher, and the $\mathrm{n}$ scale denominator is lower.

The field is displayed with less details when the $\mathrm{n}$ denominator is higher, thus the representation scale is lower.

Conventional cartographic signs are means needed for the conventional scale representation of the field in topographic and cadaster plans. Depending on the size and representation scale, there are three types of conventional signs: outlining conventional signs, scale conventional signs and explanatory conventional signs. To make a low scale plan, a high number of conventional signs are used. In the "Conventional signs atlas for topographic plans at 1:5.000, 1:1000 and 1:500 scales" 1978 edition. 
The link between the cadaster plan, the cadaster registries and the real estate register with the graphic and textual data bases of the informational cadaster system is made through the cadaster number. The cadaster number is set through separate succession for the urban and non-urban areas.

Cadaster data are registered in written documents called cadaster registries. These ones are ranked into 5 types, namely: cadaster registry of property goods, cadaster registry of allotments, cadaster registry of owners, the alphabetic index of owners, summary of cadaster parts on owners and destination of use.

\section{Building measurement}

Evaluation reports of real estate properties, for constructions and lands, includes measurement codes, through which the terms and measurement methods of used areas, surfaces and volumes are defined. This code is designed for specialists in the evaluation of real estate properties and real estate agents, for the correct and unitary use of terminology and the size, surface and volume measurement methods for constructions and lands. The measurement code is split in two parts: constructions measurement and land measurement.

\subsection{Construction measurement}

\subsubsection{Surfaces measured on the outline of the building}

To measure the outline of the building, more area types are used.

Built area - Ac - represented by the area of the building's horizontal section at $+/-0,00$ (the dimension of the finite floor of the ground floor), measured on the exterior outline of the walls. In the case of underground constructions and basements, the built area is measured at the finite dimension of the floor and is considered as the area of the horizontal section, the area within the exterior outline of the walls, including the thickness of the isolation layer. When we have buildings which are located on slopes, the built area is measured in horizontal surfaces step by step, depending on the land and the specific use of the building.

Built area per apartment - Ac-ap - represents the sum of the useful areas in the apartment, lodges and balconies, of the share from the commune areas of the building to which the area of the inside and outside walls of the apartment is added. In the case of solid fuel heating, the surface of the fireplaces and the water heaters are used.

Floor area - A niv - includes the area of the horizontal section of the building at the respective floor, limited by its external outline.

Total area - Ad - includes the sum of all floors' areas.

Total built area (for dwelling places) - shows the difference between the total area and the area of the basement.

Total external area - AET -shows the area of the building, measured from the exterior, for every floor - similar to the total area.

Total area - AT - regards the sum of all the built areas of the building, for every floor - similar to the total built area.

\subsubsection{Areas measured on the interior outline of the building}

To measure the interior outline of the building, the following area types are used:

Total interior area - AIT - regards the building surface limited by the interior outline of the external walls for every floor.

Net interal area - AIN - regards the usable area in the building, limited by the internal outline of external walls, for each floor.

Walls area - Aper - the sum of all horizontal projections' areas of the walls, panels and external and internal pillars and the chimneys.

Useful area - Au - is the unfolded area, less the area of the walls.

\subsubsection{Special use areas}

The areas with special use are used for the following properties: residential properties, industrial properties and commercial properties. For the residential properties, we use:

The useful area of the apartment - Auap - sum of all the useful areas of the spaces in the apartment, minus the areas of the lodges and balconies, the doorways, heating devices' niches, the surfaces of the fireplaces and the water heaters in the bathrooms.

The habitable area of the apartment - Aloc-ap - the sum of the areas designed for habitation.

For industrial properties, the following areas are used:

Exploitation area - Aexp - the sum of all the areas designed for the main technologic process.

Auxiliary area - Aaux - the sum of all useful area designed for the supporting technologies of the main technologic process.

Circulation area - Acirc - includes the sum of the areas inside the buildings designed for the railroads and pavement for the circulation of vehicles and the area of the hallways, stairways and elevators.

In the case of commercial properties, the following areas are used: 
Needed commercial area - An-com - the areas of the selling, consumption halls, the areas for the goods stocks and the auxiliary area.

Commercial area - Acom -includes stocking and auxiliary spaces consisting of non-structural compartments and surfaces with niches and general display arcades and the model of the shop front.

Storage area - Adep - represents the net internal area of a shop which is not included in the commercial area and which is designed for goods' storage.

Auxiliary commercial area - Acom-aux - includes all the net internal areas which are not included in the commercial and storage are but which can be exploited.

Total measured area - Atm -represents the total area of the building included in the dominant area of the height, located in the outside of the basic axis of the building. Parking lots and ramps are excluded and in the case of renting, it is calculated floor by floor.

\subsubsection{Rentable spaces description}

Rentable space per floor- the whole measured area per flood, minus the major vertical empty spaces on the same floor.

Usable area per floor - the useful area of that floor.

Common area per floor - the sum of useful areas of the common spaces on that floor. Common building space - the sum of useful areas of the common spaces of the building used by the renter, not included in exclusive spaces.

The R/U index per floor represents the conversion factor applied to the usable space, defines the rentable basic area of the office, commercial areas or the common area in the building. The rentable basic area includes the usable area of the exclusive area and the common area in the building and their corresponding part from the common area per floor. This area is determined by using the R/U index per level, for the areas of residential, or commercial areas and/or for the common area in the building. The total area of the rentable place represents the sum of all the rentable areas for each floor. The rentable surface of the building is the sum of all rentable surfaces per level.

The rentable space is determined by applying the $\mathrm{R} / \mathrm{U}$ index to the exclusively space and represents the usable area of an exclusively owned space with a share corresponding to the common surface per level.

\subsubsection{Dimensions}

When evaluating a construction, the following terms are used:

Total façade - Ft - is represented by the total external length, from the external outline of external walls or from the central part of common walls. Net façade - Fn - represents the total external façade of the shop, measured between the internal side of the external walls or the internal part of the supporting pillars. Shop width - Lt-mg - the internal width between the interior sides of the external walls, in the shop front other reference point.

Shop depth - Ad - mg - is a measurement made from the shop front to the back side of the commercial surface.

Built depth - Ad - c - is a measurement made at the ground floor of the building between the front and back walls.

\subsubsection{Volumes}

When evaluating a building, the following concepts are used:

Floor volume - V niv - product between the area of the level and its height

Level height - I niv - is measured for a current level, for the last level at buildings with attics, for the attic, for the last level at the buildings without attic.

Total volume - Vt - sum of the volumes of all levels.

Internal volume - Vint- represents the product of the total area and the internal height.

Internal height - Iint - the height between the surface of the structural level and the lowest side of the lowest point of the ceiling or structural rooftop.

\subsection{Field measurement according to the real estate evaluation}

In STAS 7468/1980, when defining the size features of fields, one uses the surface concept synonymous to the area concept, in the concept of evaluation. The field surfaces are: Precinct surface $\mathrm{Sr} / \mathrm{Si}$ : total delimited surface of the territory/field

Built surface Sc: sum of the surfaces that are definitively occupied by buildings, constructions, equipment totally/partially closed or completely open.

Network corresponding surface, Sr: the sum of surfaces covered by external networks with technologic use and underground equipment.

Transport way surface, St: the sum of surfaces of the transport ways, as well as the featured functional arrangements. 
Free surface, Sl: the sum of surfaces, other than the mentioned above ones or determined by the mandatory distances between constructions, networks and equipment, set according to the legal in force regulation.

Occupied surface, So: the sum of built surfaces, corresponding to the networks and transport ways.

The occupation percentage of the field (POT) - the occupation degree of the field (G) is a quantitative occupation index of the field and is represented by the ratio between the occupied surface and the precinct. The usage coefficient of the field (CUT) is a qualitative index for the usage of field and is represented by the ratio between the sum of extended surfaces of all the constructions and the surface of the precinct.

\section{Conclusions}

The real estate evaluation report includes all the expertise, work, efforts, knowledge and experience of a real estate evaluating agent, meets the mean through which the real estate evaluator would communicate the analysis and the results of the real estate evaluation to a client. This is based on a complete investigation, it is logically organized, solid reasoning and an accurate and systematic expression. To meet these requirements, the knowledge of the evaluation terminology is needed.

The evaluation process is a complex system including all research, information, reasoning, analysis and conclusions needed to reach the estimated value. The main scope of the evaluation process is the presentation of an impartial opinion on the value, through which the evaluator shows that he has considered all the factors that significantly influence the value. Evaluation is needed wherever a property is traded through the selling-buying process, or rented, and, usually when situations appear, where a decision must be made or it is to act or establish a strategy for which a value estimation is needed, namely the market value.

\section{References}

1. Badea Gh, Cadastru general, editura Conspress UTCB, 2005

2. Bătrâncea I. (coord.), Analiza-diagnostic şi evaluarea societăţilor comerciale, Editura Dacia,Cluj Napoca 2003

3. Crivii A., Interdependenţa metodelor de evaluare a întreprinderii, Tribuna Economică, nr.20, 2008

4. Guse R., - Valoare, pret, cost si evaluare in contabilitate,Editura C.E.C.C.A.R, Bucuresti, 2011.

5. Marin T., Iniţiere în evaluarea întreprinderilor, ediţia a IV-a, revizuită şi adăugită, Editura Ceccar, Bucuresti , 2011

6. Manaţe D., Diagnosticul și evaluarea întreprinderilor cotate şi necotate, Colecţia BibliotecaANEVAR, Editura IROVAL (Institutul Român de Cercetări în Evaluare), 2002

7. Munteanu C-tin. Gh., Cartografie matematică, editura Matrix Rom, 2003,

8. Radu Riana Iren, Econometric Model-A tool in FinancialManagement, Annals of "Dunarea de Jos" University of Galati Fascicle I. Economics and Applied Informatics Years XVII - no2/2011 ISSN 1584-0409

9. Radu Riana Iren., The Analysis of Financial Conditions Imposed by Banks for the Approval of Long Term Credits Requested by Economical Agents, Ovidius University Annals, Economic Sciences Series, Ovidius University of Constantza, Faculty of Economic Sciences, vol. 0(2), pages 684-687, October, 2007

10. Pripoaie Rodica., Statistic Analysis of the Total Number of Banking Clients within Territorial Profile During 2002, International Conference on Finance and Risk, University of Economics in Bratislava, Slovakia, November 24-25, 2008

11. Pripoaie R., The Analyze and Prognose of Risk Bankruptcy - Case Study, Arcelor Mittal Steel Galati, MIBES

12. Sion I. G., Institutii de drept si legislatie funcir cadastrală-partea speciala, editura Matrix Rom, 2003

13. Stan S.V, Anghel I, Evaluarea întreprinderii, ediţia a treia revizuită, Editura IROVAL şi INVEL MULTIMEDIA Bucureşti, 2007

14. Şchiopu C.,Burlacu C.,Peştişanu C, Construcţii, clădiri şi alte construcţii inginereşti, Colecţia Biblioteca ANEVAR

15. Tămâioagă GH, Tămâioagă D., Cadastrul general si cadastrele de specialitate, editura Matrix Rom, 2005

16. ***Simpozion stiintific, Analiza economico-financiara si evaluarea proprietatilor, Provocari in actualul context global, Bucuresti, 29-31 mai 2009 